\section{Jurnal Mitra Pendidikan (JMP Online)}

URL : http://e-jurnalmitrapendidikan.com
JMP Online

Vol. 4, No. 6, 339-349.

(C) 2020 Kresna BIP. e-ISSN 2550-0481

p-ISSN 2614-7254

\title{
MENINGKATKAN KETERAMPILAN GERAK MELALUI KEGIATAN MENARI PADA ANAK KELOMPOK B TK DIDI DODO MAUMERE
}

\author{
Anastasia Agustalis \\ TK Didi Dodo Maumere Kabupaten Sikka
}

INFORMASI ARTIKEL

Dikirim : 26 Juni 2020

Revisi pertama : 27 Juni 2020

Diterima : 29 Juni 2020

Tersedia online: 02 Juli 2020

Kata Kunci: Keterampilan Gerak, Kegiatan Menari, Taman Kanak-Kanak

Email: anastasia03@gmail.com
ABSTRAK

Tujuan dari penelitian ini adalah untuk mengetahui peningkatan keterampilan gerak anak anak kelompok B melalui kegiatan menari di TK Didi Dodo Maumere.

Penelitian ini menggunakan metode penelitian tindakan kelas secara deskriptif dengan subjek guru dan 16 anak-anak kelompok B TK Didi Dodo Maumere. Hasil analisis data keterampilan gerak anak melalui kegiatan menari menunjukkan bahwa: aktivitas anak pada siklus I dan sebesar 37,5\% dan siklus II sebesar $87,5 \%$. Pelaksanaan pembelajaran meningkat dengan nilai rata-rata siklus I sebesar 31,25\% dan pada siklus II sebesar 100\%.

Peningkatan pembelajaran keterampilan gerak pada indikator anak dapat melakukan koordinasi gerak kepala, tangan, dan kaki meningkat menjadi $100 \%$, anak dapat melakukan gerak dengan lincah meningkat menjadi $100 \%$ dan anak bergerak sesuai dengan irama musik meningkat menjadi $100 \%$. 


\section{PENDAHULUAN \\ Latar Belakang}

Anak sebagai penerus generasi keluarga dan bangsa, perlu mendapat pendidikan anak, sehingga potensi-potensi dirinya dapat berkembangdengan pesat, diharapkan akan tumbuh menjadi manusia yang memiliki kepribadian yang tangguh dan memiliki berbagai macam kemampuan dan keterampilan yang bermanfaat. Oleh karena itu, proses pendidikan untuk memberikan stimulus dan bimbingan yang tepat sangat penting dalam mengembangkan dan mengaktualisasikan peserta didik dengan maksimal sesuai dengan bakat dan minatnya yang dapat dilakukan secara formal maupun informal. Dengan demikian pendidikan anak usia dini sangat menunjang berbagai potensi pada anak dimasa depan, salah satunya pada perkembangan fisik/motorik anak.

Dalam penelitian Gallahue (dalam Winda Gunarti dkk, 2008: 1.28) menyatakanbahwa usia prasekolah merupakan waktu yang paling optimal untuk perkembangan motorik anak. Perkembangan motorik anak akan terlihat di saat anak melakukan berbagai aktivitas seperti berjingkrak-jingkrak, melompat, berlari ataupun sekedar berjalan-jalan yang mana dalam pelaksanaannya memerlukan koordinasi antara anggot atubuh. Aktivitas-aktivitas tersebut termasuk dalam keterampilan gerak tubuhnya. Keterampilan gerak ini merupakan kemampuan yang dimiliki anak untukmelakukan suatu tugas gerak tertentu secara maksimal sehingga perlu dilatih sebaik mungkin di usia dini sehingga nantinya anak akan semakin terampil melakukan berbagai gerakan tersebut. Perkembangan gerak pada anak bisa terjadi dengan baik apabila anak memperoleh kesempatan cukup besar untuk melakukan aktivitas fisik dalam bentuk gerakan-gerakan yang melibatkan keseluruhan bagian anggota tubuhnya, sehingga anak akan mampu mengusai keterampilan gerak dengan baik. Seseorang yang telah menguasai keterampilan gerak secara baik dan mumpuni setidaknya telah punya bekal yang sangat penting dan berguna untuk menapaki kehidupan menuju hari depan yang lebih baik (Heri Rahyubi, 2011: 210). Penguasaan keterampilan gerak yang baik bisa didaya gunakan seseorang untuk meraih prestasi di bidang olah raga, seni, musik, dunia kerja yang beragam, dan berbagai profesi. Keterampilan gerak dapat diterapkan dalam aneka permainan, olahraga dan aktivtas jasmani yang dilakukan dalam kehidupan sehari-hari, salah satunya kegiatan menari. Kesenian menari sendiri yaitu jenis kesenian yang berhubungan langsung dengan gerak tubuh manusia. Bagian-bagian anggota tubuh yang dapat digerakkan dalam kegiatan menari meliputi kepala, badan, tangan dan kaki. Tanpa gerak, maka kegiatan menari tidak dapat ditampilkan. Hal ini dikarenakan elemen dasar dari tari adalah gerak. Berbagai macam jenis gerak dapat dijadikan dasardalam menari, dimana dalam menampilkannya dibutuhkan sebuah keterampilan.

Dengan demikian, kegiatan menari secara tidak langsung akan membuat seorang anak yang melakukannya akan memiliki keterampilan dalam bergerak. Sepertiyang diungkap oleh Tetty Rachmi, dkk (2008:9.15) mengatakan bahwa dengan menari, berarti anak telah terampil dalam bergerak. Dalam Peraturan Menteri Pendidikan Nasional No. 58 tahun 2009 dijelaskan bahwa anak usia 5 - 6 tahun, tingkat pencapaian motorik kasar pada anak diantaranya adalah melakukan koordinasi gerakan kaki, tangan, kepala dalam melakukan tarian/senam. Tingkat 
pencapaian perkembangan ini terdiri dari beberapa indikator diantaranya menggerakkan kepala, tangan, dan kaki denganbenar secara bersamaan dalam gerak bervariasi, menampilkan gerakan kepala, tangan dan kaki dengan lincah, serta dapat bergerak sesuai dengan irama musik yang di dengar.

Untuk itu guru sebagai peneliti akan melakukan penelitian tindakan kelas dengan judul "Meningkatan Keterampilan Gerak Melalui Kegiatan Menari pada Anak Kelompok B di TK Didi Dodo Maumere".

\section{Rumusan Masalah}

Berdasarkan latar belakang diatas, maka masalahanya adalah bagaimana meningkatkan keterampilan gerak melalui kegiatan menari pada anak kelompok B di TK Didi Dodo Maumere?.

\section{Tujuan Penelitian}

Berdasarkan rumusan masalah diatas, maka tujuan dalam penelitian ini adalah untuk mengetahui peningkatan keterampilan gerak melalui kegiatan menari pada anak kelompok B di TK Didi Dodo Maumere. Serta Mendeskripsikan perencanaan pembelajaran kegiatan menari untuk meningkatkan keterampilan gerak pada anak kelompok B TK Didi Dodo Maumere.

\section{Manfaat Penelitian}

Manfaat penelitian ini adalah untuk dapat menjadi solusi pemecahan masalah dalam dunia pendidikan, terutama bagi peneliti/guru, peserta didik dan bagi lembaga.

\section{KAJIAN PUSTAKA \\ Pengertian Gerak}

Gerak adalah aksi atau proses perubahan letak atau posisi ditinjau dari suatu titik tertentu sebagai pedomannya. Sedangkan keterampilan dapat didefinisikan sebagai kecakapan dan ketetapan dalam melaksanakan tugas. Keterampilan gerak merupakan gambaran kemampuan seseorang yang ditunjukkan dalam penguasaan suatu gerakan untuk melakukan suatu tugas gerak secara maksimal. Menurut Sugiyanto (2001:8.11), gerakan keterampilan merupakan salah satu kategori gerakan yang dalam melakukannya diperlukan koordinasi dan kontrol tubuh secara keseluruhan atau sebagian tubuh. Koordinasi dan kontrol tubuh yang baik akan meningkatkan keterampilan dalam melakukan gerakan. Untuk memperoleh keterampilan gerak ini dibutuhkan stimulasi yang baik. Seperti yang diungkapkan oleh Pavlov (dalam Heri Rahyubi, 2012:162) mengatakan bahwa kunci utama keahlian dan keterampilan gerak ada pada stimulasi yang diberikan. Semakin baik penguasaan gerak keterampilan, maka pelaksanaannya akan semakin efisien. Bagi anak usia dini keterampilan gerak dapat dilakukan melalui berbagai aktivitas yang dapat membuat mereka selalu bergerak, karena pada dasarnya karakteristik anak usia dini adalah selalu bergerak. Dengan bergerak mereka dapatmenemukan pengetahuannya sendiri, bereksplorasi, dan mengembangkan berbagai aspek perkembangannya baik psikomotor, kognitif, 
maupun afektifnya. Hal ini diperkuat oleh Henniger (2009.p.24), yang menyatakan bahwa :

Movement is at the very center of young children's lives. It is an important face of all aspects of their development, whether in the motor, cognitive, or affective domains of human behavior. To deny children the opportunity to reap the many benefits of regular, vigorous physical activity is to deny them the opportunity to experience the joy of efficient movement, the health effects of movement, and a lifetime as confident, competent movers.

Dengan kata lain anak-anak dapat mengungkap gagasan, perasaan atau emosi lewat gerak. Pernyataan tersebut juga diungkap oleh Carol dan Barbara (2008:301) yang menambahkan bahwa mereka anak-anak bisa mengungkapkan perasaan dan pengalaman mereka dengan imajinasi dan pikiran yang terlibat untuk bergerak kreatif, dengan mengontrol keterampilan motorik, memungkinkan pengungkapan simbolis. Anak usia dini memiliki proses pertumbuhan dan perkembangan fisik dan otak yang sangat pesat. Pemberian stimulasi yang sesuai dengan karakteristik perkembangan anak akan menjadikan anak berkembang secara maksimal, termasuk perkembangan fisiknya. Pada masa ini dianggap sebagai masa yang paling potensial dalam sepanjang rentang perkembangan kehidupan seorang anak manusia untuk mengembangkan fisik atau jasadnya maupun keterampilan dari gerak tubuhnya (Winda Gunarti, 2008:1.28)

Menanamkan latihan keterampilan gerak yang benar sangatlah penting terutama untuk anak usia dini. Hal ini dikarenakan pada usia dini merupakan masa dasar dari perkembangan dan pertumbuhan, sehingga nantinya diharapkan anak dapat melakukan aktivitas fisik dengan terampil yang berguna dalam melakukan tugas gerak fisik dalam kehidupan sehari-hari. Pembelajaran keterampilan gerak di Taman Kanak-Kanak telah diatur dalam Peraturan Menteri Pendidikan Nasional Republik Indonesia No. 58 tahun 2009, dalam lingkup perkembangan "Motorik Kasar". Pada tingkat pencapaian perkembangan untuk anak usia 5-6 terdapat beberapa aspek yang perlu dikembangkan, diantaranya adalah melakukan koordinasi gerakan kaki-tangan-kepala dalam melakukan tarian / senam. Dalam aspek melakukan koordinasi gerakan kaki-tangan-kepala dalam tarian/senam terdapat diantaranya indikator: "menggerakkan kepala, tangan, dan kaki denganbenar secara bersamaan dalam gerak bervariasi, menampilkan gerakan kepala, tangan, dan kaki dengan lincah, serta dapat bergerak sesuai dengan irama musik yang didengar". Secara umum pendidikan pada anak usia dini bertujuan untuk membantu mengembangkan seluruh potensi dan kemampuan fisik, intelektual, emosional, moral dan agama secara optimal pada anak dalam lingkungan pendidikan yang kondusif, demokratis dan kompetitif (Puskur, 2002). Keterampilan gerak dapat diterapkan dalam aneka permainan, olahraga dan aktivtas jasmani yang dilakukan dalam kehidupan sehari-hari, salah satunya kegiatan menari. Kesenian menari sendiri yaitu jenis kesenian yang berhubungan langsung dengan gerak tubuh manusia.

Menurut Alfi Manzilatur Rohma (2013:2), menyatakan bahwa tari merupakan gerakan yang ritmis, gerak yang bersifat non-representative, yaitu gerak yang tidak menggambarkan apapun kecuali semata-matahanya mengandalkan kemampuan fisik dari tubuh dalam menterjemahkan pola ruang dan 
waktunya yang khas. Bagian-bagian anggota tubuh yang dapat digerakkan dalam kegiatan menari meliputi kepala, badan, tangan dan kaki. Tanpa gerak, maka kegiatan menari tidak dapat ditampilkan. Hal ini dikarenakan elemen dasar dari tari adalah gerak. Pembelajaran keterampilan gerak melalui kegiatan menari adalah upaya melatih kemampuan fisik anak melalui kegiatan yang menyenangkan, ekspresif dan kreatif bagi anak, karena selain melatih kemampuan fisik, menari juga dapat menyalurkan perasaan anak. Sumandiyo Hadi (2005:36), mengatakan bahwa menari digunakan untuk mempresentasikan banyak perasaan seperti kebebasan, harapan, gairah, kekuatan, dan keagungan.

Bagi anak usia dini, fungsi tari sangat mempengaruhi perkembangan semua aspek perkembangannya. Seperti yang diungkap oleh Isaac Waswa Shitubi and Mellitus N. Wanyama (2012:232) mengatakan bahwa : The term 'Music and Movement' often especially denotes theuse of rhythmic songand dance in education, thought of as beneficial for childhood development.

Dengan kata lain bahwa musik dan gerakan atau tari dapat mengembangkan semua aspek perkembangannya, terutama keterampilan gerak anak. Melalui kegiatan menari anak akan bergerak mengikuti gerakan yang ada dalam kegiatan menari dengan senang hati sehingga anak akan semakin terampil dalam bergerak. Hal ini dikarenakan anak usia dini pada dasarnya merupakan makhluk yang senang bergerak. Dengan menari, banyak kemampuan yang diperoleh anak seperti anak belajar cara baru berpikir menghafal gerakan dalam tarian, menghafal desain lantai yang bervariasi dan harus mampu mendengar iringan musik serta menyesuaikan iringan dengan gerakannya.

\section{Hipotesis Tindakan}

Jika guru meningkatkan keterampilan gerak melalui kegiatan menari maka dapat meningkatkan prestasi belajar anak kelompok B TK Didi Dodo Maumere.

\section{METODE PENELITIAN Jenis Penelitian}

Penelitian yang digunakan adalah Penelitian Tindakan Kelas (PTK), yang dilakukan di dalam kelas dengan tujuan untuk meningkatkan keterampilan gerak melalui kegiatan menari yang dapat meningkatkan prestasi belajar anak kelompok B TK Didi Dodo Maumere.

\section{Tempat, Waktu dan Subjek Penelitian}

Penelitian ini dilaksanakan di TK Didi Dodo Maumere pada bulan Agustus hingga September 2019. Adapun subjek dalam penelitian ini adalah anak kelompok B TK Didi Dodo Maumere yang berjumlah 16 siswa, yang terdiri 11 laki-laki dan 5 perempuan. 


\section{Prosedur Penelitian}

Rencana penelitian ini dilaksanakan sampai siklus kedua. Setiap siklus dilakukan empat kegiatan sebagai berikut :

a. Siklus pertama

1. Tahap perencanaan tindakan yang disiapkan antara lain

a) Pedoman observasi untuk menilai

b) Pelaksanaan langkah- langkah pembelajaran

c) Keaktifan anak selama pembelajaran

d) Respon anak tentang pelaksanaan pembelajaran

e) Soal tes bagi yang melihat hasil belajar

f) Materi ajar

g) Media pembelajaran

h) Pedoman penilaian

2. Tahap pelaksanaan tindakan : semua yang disiapkan pada tahap perencanaan tindakan digunakan pada tahap ini.

3. Tahap observasi dan evaluasi, dilaksanakan bersamaan dengan tahap pelaksanaan Tindakan. Pada tahap ini digunakan semua pedoman observasi untuk mengumpulkan data tentang dampak atau hasil pembelajaran.

4. Tahap refleksi, merenungkan ulang pelaksanaan pembelajaran dan hasil pada siklus pertama. Yang direnungkan adalah :

- Bagaiman pelaksanaan pembelajaran ?

- Apa akibatnya?

Hasil refleksi ini akan menentukan apakah pembelajaran diteruskan ke siklus berikutnya atau cukup.

b. Siklus kedua

Dilakukan berdasarkan hasil refleksi tentang kegiatan siklus pertama, apa saja yang dilakukan pada :

1. Tahap perencanaan tindakan, yang di siapkan antara lain :

a) Pedoman observasi untuk menilai pelaksanaan langkah-langkah pembelajaran, peran guru selama pembelajaran, keaktifan anak selama pembelajaran (harus dilihat keaktifan anak secara keseluruhan, respon anak tentang pelaksanaan pembelajaran)

b) Soal tes bagi yang melihat hasil belajar

c) Materi ajar

d) Pedoman penilaian.

2. Tahap pelaksanaan tindakan: semua yang disiapkan pada tahap perencanaan tindakan digunakan pada tahap ini.

3. Tahap observasi dan evaluasi, dilaksanakan bersamaan dengan tahap pelaksanaan tindakan. Pada tahap ini digunakan semua pedoman observasi untuk mengumpulkan data penelitian (aspek proses) dan soal tes digunakan untuk mengumpulkan data tentang dampak atau hasil pembelajaran.

4. Tahap refleksi, merenungkan ulang pelaksanaan pembelajaran dan hasil pada siklus pertama.

- Bagaimana pelaksanaan pelajaran?

- Apa saja keunggulan atau kelebihan dalam pelajaran?

- Apa akibatnya? 
- Apa saja kelemahan atau kekurangandalam pembelajaran tadi yang perlu diperbaiki dan apa akibatnya?

- Apa upaya untuk memperbaiki kelemahan atau kekurangan tadi yang akan dilakukan pada siklus berikut?

Hasil refleksi ini akan menentukan apakah pembelajaran diteruskan ke siklus berikutnya atau cukup.

\section{Indikator Perbaikan Pembelajaran}

1. Segi proses: Pelaksanaan tindakan pemecahan masalah. Contoh indikator perbaikan proses pembelajaran adalah Pelaksanaan keterampilan gerak melalui kegiatan menari (meliputi langkah-langkah pelaksanaan pembelajaran, peran guru dalam pembelajaran, keaktifan anak dalam pelaksanaan pembelajaran, respons anak tentang pelaksanaan pembelajaran motorik kasar.

2. Segi hasil : Dampak dari tindakan pemecahan masalah.

\section{Teknik Pengumpulan Data}

1. Teknik pengumpulan data yang umum digunakan adalah teknik observasi. Instrumen pengumpulan data: pedoman observasi (berupa daftar cek, skala penilaian, catatan kejadian, dan lain-lain)

2. Tes. Instrumen pengumpulan data soal adalah soal tes yang valid dan reliable

\section{Teknik Analisa Data} penelitian

Statistik deskriptif sederhana. Menghitung refleksi dan prosentase hasil

a. Siklus pertama :

1) Langkah-langkah pelaksanaan pembelajaran

2) Peran guru dalam pembelajaran

3) Keaktifan anak dalam pembelajaran

4) Respon anak tentang pelaksanaan pembelajaran; maupun aspek hasil meliputi prestasi belajar

b. Siklus kedua. Aspek proses: meliputi

1) Langkah-lagkah pelaksanaan pembelajaran

2) Peran guru dalam pembelajaran

3) Keaktifan aanak dalam pembelajaran

4) Respon anak tentang pelaksanaan pembelajaran, maupun aspek hasil meliputi prestasi belajar.

c. Perbandingan antara hasil penelitian siklus pertama dan hasil penelitian siklus kedua (baik aspek proses):

1) Langkah-langkah pelaksanaan pembelajaran

2) Peran guru dalam pembelajaran

3) Keaktifan anak dalam pembelajaran

4) Respon anak tentangpelaksanaan pembelajaran maupun aspek hasil meliputi hasil belajar.

Untuk melihat ada tidak peningkatan perbaikan pembelajaran dan hasil. Aspek proses : meliputi

1) Langkah-langkah pelaksanaan pembelajaran 
2) Peran guru dalam pembelajaran

3) Keaktifan anak dalam pembelajaran

4) Respon anak tentang pelaksanaan pembelajaran.

Aspek hasil meliputi : Prestasi belajar

\section{HASIL PENELITIAN DAN PEMBAHASAN}

\section{Hasil Penelitian}

\section{Siklus I}

Sebelum melakukan pelaksanaan siklus I maka sebelumya peneliti akan melakukan perencanaan terlebih dahulu. Setelah semuanya perencanaan sudah baik maka akan di lakukan penelitian siklus I. Penelitian siklus I ini di laksanakan pada bulan Agustus sampai dengan bulan Oktober 2019. Obyek yang di teliti adalah anak-anak kelompok B Tk Didi Dodo yang berjumlah 15 orang dengan menggunakan teknik analisa data dan deskripsi enelitian secara verbal. Untuk lebih jelasnya kita dapat melihat penjelasan di bawah ini.

Dari hasil pengamatan penulis pada kegiatan pembelajaran pada siklus I belum memuaskan, artinya sudah terjadi peningkatan moral pada anak namun belum mencapai hasil yang diharapkan. Untuk lebih jelasnya dapat dilihat pada tabel 1 .

Tabel 1. Data Hasil Observasi Keterampilan Gerak Anak Melalui Kegiatan Menari pada Siklus I

\begin{tabular}{|c|c|c|c|c|c|c|c|c|}
\hline \multirow{2}{*}{ No } & \multicolumn{4}{|c|}{ Kategori } & \multirow{2}{*}{ Interval } & \multirow{2}{*}{$\begin{array}{c}\text { Frekuensi } \\
(\mathbf{N})\end{array}$} & \multirow{2}{*}{$\begin{array}{c}\text { Prosentase } \\
(\%)\end{array}$} & \multirow{2}{*}{ Keterangan } \\
\hline & $\mathbf{A}$ & $\mathbf{B}$ & C & $\overline{\mathbf{D}}$ & & & & \\
\hline 1 & $\sqrt{ }$ & & & & - & - & - & \multirow{7}{*}{$\begin{array}{l}\text { A= SANGAT } \\
\text { BAIK } \\
\text { B=BAIK } \\
C=\text { CUKUP } \\
D=\text { KURANG }\end{array}$} \\
\hline 2 & & $\sqrt{ }$ & & & 6 & 0,37 & 37,5 & \\
\hline 3 & & & $\sqrt{ }$ & & 5 & 0,31 & 31,25 & \\
\hline 4 & & & & $\sqrt{ }$ & 5 & 0,31 & 31,25 & \\
\hline & & & & & & & & \\
\hline & & & & & & & & \\
\hline & & & & & & & & \\
\hline & JUN & ILA & & & 16 & 1 & 100 & \\
\hline
\end{tabular}

Sumber : Hasil Penelitian, diolah (2019)

Dari tabel di atas menunjukan bahwa aktivitas anak dalam gerak melalui kegiatan menari cukup baik. Jumlah anak yang melakukan gerak dan menari dengan baik ada 6 orang atau sebesar 37,5\% dan yang belum sebanyak 10 orang atau sebesar 62,5\%, maka aktifitas anak kelompok B perlu ditingkatkan pada siklus II.

Tabel 2. Hasil Nilai Keberhasilan Anak Kelompok A pada Siklus I

Keterangan :

\begin{tabular}{|c|c|c|}
\hline No & Kategori & Jumlah \\
\hline 1 & MB & 4 \\
\hline 2 & BSH & 6 \\
\hline 3 & BSB & 5 \\
\hline
\end{tabular}

Sumber : Hasil Penelitian, diolah (2019)

$\mathrm{MB}=$ Mulai Berkembang

BSH = Berkembang Sesuai Harapan

BSB = Berkembang Sangat Baik 
Pada tabel diatas yang menjadi kriteria penilaian di lihat pada keterangan di atas maka jumlah anak yang dinilai $\mathrm{MB}=5$ orang, $\mathrm{BSH}=6$ orang dan $\mathrm{BSB}=5$ orang. Dengan demikian prosentase ketuntasan anak mencapai $31,25 \%$ yang di peroleh dari jumlah anak yang mendapat nilai BSB dibagi dengan jumlah seluruh anak. Sedangkan jumlah anak yang belum mencapai BSB sebanyak 11 orang dengan prosentase $68,75 \%$. Hasil yang dicapai pada siklus I belum tuntas maka peneliti akan melaksanakan penelitian ulang ke siklus II.

Peneliti akan melakukan penelitian siklus II yaitu dengan memperbaiki semua kekurangan yang terjadi pada siklus I. Sebelum melakukan pelaksanaan siklus I seperti biasanya harus melakukan perencanaan yang lebih matang bila di bandingkan pada siklus I agar tidak terjadi kendala.

Tabel 3. Hasil Pengamatan Anak Kelompok B pada Siklus II

\begin{tabular}{|c|c|c|c|c|c|c|c|c|}
\hline \multirow{2}{*}{ No } & \multicolumn{4}{|c|}{ Kategori } & \multirow[b]{2}{*}{ Interval } & \multirow{2}{*}{ Frekuensi (N) } & \multirow{2}{*}{ Prosentase (\%) } & \multirow{2}{*}{ Keterangan } \\
\hline & $\mathbf{A}$ & B & C & D & & & & \\
\hline 1 & $\sqrt{ }$ & & & & 14 & 0,87 & 87,5 & \multirow{2}{*}{$\begin{array}{c}\mathrm{A}=\text { SANGAT } \\
\text { BAIK } \\
\mathrm{B}=\mathrm{BAIK} \\
\mathrm{C}=\text { CUKUP } \\
\mathrm{D}=\text { KURANG }\end{array}$} \\
\hline 2 & & $\sqrt{ }$ & & & 2 & 0,12 & 12,5 & \\
\hline & $\overline{\mathrm{JUN}}$ & $\overline{\mathrm{ILA}}$ & & & 16 & 1 & 100 & \\
\hline
\end{tabular}

Sumber : Hasil Penelitian, diolah (2019)

Dari tabel di atas menunjukan bahwa hasil pengamatan anak kelompok B dalam mengikuti kegiatan menari pada siklus II mengalami kemajuan yang sangat baik dimana 14 orang mendapat kategori A atau sangat baik dan 2 orang mendapat kategori B atau baik dengan prosentase sebesar $100 \%$ artinya sangat memuaskan.

Tabel 4. Hasil Nilai Keberhasilan Anak Kelompok B Pada Siklus I

\begin{tabular}{|c|c|c|}
\hline No & Kategori & Jumlah \\
\hline 1 & MB & - \\
\hline 2 & BSH & 2 \\
\hline 3 & BSB & 13 \\
\hline \multicolumn{3}{|c|}{ Sumber : Hasil Penelitian, diolah (2019) }
\end{tabular}

Keterangan :

$\mathrm{MB}=$ Mulai Berkembang

$\mathrm{BSH}=$ Berkembang Sesuai Harapan

$\mathrm{BSB}=$ Berkembang Sangat Baik

Pada tabel diatas menunjukan bahwa hasil yang dicapai anak sangat baik dimana jumlah anak yang mendapat nilai BSB sebanyak 14 orang dan yang mendapat nilai $\mathrm{BSH}$ sebanyak 2 orang. Dan prosentase ketntasan yang dicapai meningkat menjadi $100 \%$. Dengan melihat hail yang sangat memuaskan ini maka peneliti tidak melakukan penelitian ke siklus berikutnya. 


\section{Pembahasan}

Berdasarkan hasil penelitian yang di capai pada siklus I dan siklus II maka kita dapat melihat tabel aktivitas dan nilai anak kelompok B di bawah ini:

Tabel 5. Rekapitulasi Hasil Aktivitas dan Nilai Anak Kelompok B pada Siklus I dan Siklus II

\begin{tabular}{|l|l|l|l|}
\hline \multirow{2}{*}{ No } & \multicolumn{1}{|c|}{ Uraian } & \multicolumn{1}{c|}{ Persentase Perolehan ( \% ) } \\
\cline { 3 - 4 } & \multicolumn{1}{|c|}{ Siklus I } & \multicolumn{1}{c|}{ Siklus II } \\
\hline 1 & Aktivitas Anak kelompok B & 37,5 & 87,5 \\
\hline 2 & Hasil Nilai & 31,25 & 100 \\
\hline
\end{tabular}

Sumber : Hasil Penelitian, diolah (2019)

Aktivitas anak pada siklus I mencapai 37,5\% dan pada siklus II mencapai $87,5 \%$, maka tingkat kenaikan mencapai $40 \%$. Sedangkan hasil nilai pada siklus I mencapai $31,25 \%$ dan naik menjadi $100 \%$, maka tingkat kenaikan sebesar $68,75 \%$. Hasil penelitian ini cukup baik dan peneliti tidak melakukan penelitian lanjutan tetapi dengan penerapan ilmu yang diteliti akan dipraktikkan langsung kepada anak didik di TK Didi Dodo Maumere.

\section{KESIMPULAN DAN SARAN Kesimpulan}

Berdasarkan hasil penelitian secara umum dapat disimpulkan bahwa kegiatan menari dalam pembelajaran dapat meningkatkan keterampilan gerak anak kelompok B TK Didi Dodo Maumere. Hal ini ditunjukkan dengan meningkatnya keterampilan gerak dalam aspek melakukan koordinasi gerak kepala, tangan, dan kaki secara bersamaan dalam kegiatan menari, melakukan gerak dengan lincah, dan bergerak sesuai dengan irama musik. Secara khsusus dapat disimpulkan sebagai berikut :

1. Perencanaan pembelajaran untuk meningkatkan keterampilan gerak anak melalui kegiatan menari dikategorikan sangat baik. Hal ini berarti perencanaan pembelajaran telah disusun sesuai dengan tujuan penelitian dan memenuhi langkah-langkah penyusunan sesuai dengan kurikulum 2013.

2. Pelaksanaan pembelajaran untuk meningkatkan keterampilan gerak anak melalui kegiatan menari dikategorikan sangat baik. Ini berarti pelaksanaan pembelajaran untuk meningkatkan keterampilan gerak telah dilaksanakan sesuai dengan perencanaan pembelajaran yang telah dibuat.

3. Hasil peningkatan keterampilan gerak anak melalui kegiatan menari dapat dikatakan baik. Hal ini ditunjukkan pada setiap aspek penilaian yang mengalami peningkatan.

\section{Saran}

Berdasarkan kesimpulan di atas, peneliti menyarankan hal-hal berikut ini :

1. Perencanaan pembelajaran melalui kegiatan menari untuk meningkatkan keterampilan gerak anak yang disusun oleh guru, hendaklah direncanakan dan dilaksanakan secara berkelompok, sehingga memudahkan guru dalam mengamati dan membimbing anak. 
2. Tempat yang digunakan untuk pelaksanaan pembelajaran melalui kegiatan menari hendaklah disiapkan dalam kondisi yang cukup luas sesuai dengan tujuan pembelajaran.

3. Setiap pembelajaran kegiatan menari untuk meningkatkan keterampilan gerak anak hendaklah direncanakan dengan alokasi waktu yang tepat, seperti dalam memberi arahan dan memberikan kesempatan anak menari.

4. Kegiatan menari yang diajarkan guru kepada anak hendaklah menggunakan lagu yang sesuai dengan karakteristik anak.

5. Gerakantari yang diajarkan guru kepada anak hendaklah gerakan yang diolah dari gerak keseharian anak dan divariasikan dengan lagu anak sehingga anak lebih mudah menyerap dan mengikuti gerakan tersebut.

6. Kegiatan menari dapat dijadikan sebagai salah satu cara untuk meningkatkan keterampilan gerak anak, oleh karena itu guru hendaknya dapat mengembangkan dan menerapkan pembelajaran melalui kegiatan menari secara baik dan rutin.

7. Bagi peneliti lanjutan, diharapkan dapat melakukan penelitian tentang kegiatan menari untuk mengembangkan aspek perkembangan anak lainnya seperti aspek kognitif dan sosial emosional.

\section{DAFTAR PUSTAKA}

Departemen Pendidikan Nasional. 2009. Peraturan Menteri Pendidikan Nasional Nomor 58 tentang Standar Pendidikan Anak Usia Dini. Direktorat Jenderal Manajemen Pendidikan Dasar dan Menengah Depdiknas. Jakarta.

Guniarti, Winda,dkk. 2008. Metode Pengembangan Perilaku dan Kemampuan Dasar Anak Usia Dini. Jakarta : Universitas Terbuka

Hadi, Sumandiyo. 2005. Sosiologi Tari. Yogyakarta : Pustaka

Henniger, M.L. 2009. The Importance Of Motor Skills. Teaching young children : An Introduction. Retrieved from dahperd journal : A Practical Method for Assessing Locomotor Skills in Elementary Children. Vol. 50, April 2013 : Oklahoma State University.

Rachmi, Tetty, dkk. 2008. Keterampilan Musik dan Tari. Jakarta : Universitas Terbuka

Rahyubi, Heri. 2012. Teori-Teori Belajar dan Aplikasi Pembelajaran Motorik. Bandung : Nusa Media

Seefeldt, Carol dan Barbara A.Wasik. 2008. Early Education: Three-, Four-, and Five- Year-Olds Go To School / Pendidikan Anak Usia Dini. Edisi Bahasa Indonesia. Diterjemahkan Pius Nasar Jakarta : PT. Indeks

Sudono Anggani. 2001. Sumber belajar dan Alat Permainan Untuk pendidikan Anak Usia Dini. PT. Grasindo, Jakarta.

Sugiyanto. 2001. Pengembangan dan Belajar Motorik. Jakarta : Universitas Terbuka

Taniredja, Tukiran dkk. 2012. Penelitian Tindakan Kelas, untuk Pengembangan Profesi Guru, Praktik, Praktis dan Mudah. Alfabeta. Bandung. 